\title{
Biochemical and Histological Alterations in the Digestive Gland of the Land Snail Helicella vestalis (Locard, 1882) Exposed to Methiocarb and Chlorpyrifos in the Laboratory
}

\section{Sharaf $\mathrm{HM}^{*}$, Salama MA and Abd El-Atti MS}

Department of Zoology, Faculty of Science, Zagazig University, Egypt

\begin{abstract}
This study investigated the impact of two pesticides namely: Methiocarb and Chlorpyrifos against the biochemical and histological aspects of the helicid land snail, Helicella vestalis at Sharkia Governorate, Egypt.

The activities of three vital enzymes, total protein (TP) and total lipid (TL) were laboratory tested. These enzymes were Aspartate amino transaminase (AST), Alanine amino transaminase (ALT) and Alkaline phosphatase (ALP). Results showed that all tested pesticides lead to increase the activity of AST, ALT and ALP in the tissue homogenate of the digestive gland of the land snail Helicella vestalis. On the other hand, the levels of total protein and total lipid were increased after treatment with all tested pesticides. In general, the two pesticides were significantly affected on the activities of enzymes, total lipid and total protein compared with control when applied against the tested snails.

Meanwhile, many histological changes were observed in the digestive gland of $H$. vestalis after exposure to sublethal concentrations of both Methiocarb and Chlorpyrifos. These alterations included severe tubular disruption, vaculation, nuclear pyknosis and necrosis of tubules. Moreover, this study revealed that Chlorpyrifos was much more toxic to the tested snail than Methiocarb.
\end{abstract}

Keywords: ALP; ALT; AST; TL; TP; Chlorpyrifos; Digestive gland; Helicella vestalis; Methiocarb

\section{Introduction}

Land snails (Mollusca: Gastropoda) are serious pests in nurseries, greenhouses, orchards and filed crops in many parts of the world. In Egypt, the land snails, Helicella vestalis became the most important agricultural pests causing substantial damage to different crops in Delta region [1-6]. Control of snails on different crops is heavily dependent on the use of pesticides that limit the effect of these pests below damaging level. Hence, the synthetic molluscicides or pesticides are the most effective measures available at present for the control of terrestrial gastropods [7-12].

The effect of Methomyl and Copper Sulphate on Eobania vermiculta and Helicella vestalis snails under laboratory and field conditions was evaluated at Sharkia Governorate. Results revealed that, the mortality percentages increased with increasing the concentration values and the duration of exposure $[13,14]$.

Carbamates are known to act as nervous toxins by inhibition of cholinesterase. On the other hand, metaldehyde pesticides cause an excessive increase of fluid excretion in the soft snail body, leading to snail death [15]. Both carbamate and organophosphates pesticides are successfully used in Egypt and many other countries for controlling land snails $[8,9]$.

Methiocarb is a carbamate pesticide which is used as a bird repellent, insecticide, acaricide and molluscicide since the 1960s. It acts as contact and stomach poison on mites and has neurotoxic effects on molluscs [16]. Chlorpyrifos is highly toxic to freshwater fish and aquatic invertebrates. Cholinesterase inhibition was observed in acute toxicity tests of fish exposed to very low concentrations of this insecticide [17]. The toxic action of methomyl and methiocab on Eubania vermiculata digestive gland is evaluated [18], methomyl was more toxic than Methiocarb and the digestive gland tissues suffered from hemocytes infiltration, bizarre nuclei ranged from karyolysis to severe karyorrhexis and complete pyknosis. The effect of Thiometoxam on the histology and total carbohydrates, proteins and lipids of the hepatopancreas of Helix aspersa is studied [19]; they found a significant decrease in total proteins, lipids, and carbohydrates as well as degeneration of the digestive tubules and breakdown of the basement membrane.

This research was planned to determine the biochemical effects of two pesticides namely, Methiocarb and Chlorpyrifos on the land snail $H$. vestalis on the activities of three vital enzymes. Also, total proteins (TP) and total lipids (TL) were measured to spot a light on the toxicity of such chemicals. The enzymes measured in this study were; Aspartate amino transaminase (AST), Alanine amino transaminase (ALT) and Alkaline phosphatase (ALP).

Besides, the effect of sublethal concentrations of the two pesticides on the histology of the digestive gland using light microscopy has been studied.

\section{Material and Methods}

\section{Tested snails}

Adult land snails Helicella vestalis were collected from infested fields in Belbais City, Sharkia Governorate, Egypt, during the spring of 2014. The collected snails were transferred to the laboratory, and then

*Corresponding author: Hesham M Sharaf, Department of Zoology, Faculty of Science, Zagazig University, Cairo, Egypt, Tel: 0020133221937; E-mail: Sharaf_hesham@yahoo.com

Received March 25, 2015; Accepted May 20, 2015; Published May 22, 2015.

Citation: Sharaf HM, Salama MA, Abd El-Att MS (2015) Biochemical and Histological Alterations in the Digestive Gland of the Land Snail Helicella vestalis (Locard, 1882) Exposed to Methiocarb and Chlorpyrifos in the Laboratory. J Cytol Histol 6: 327. doi:10.4172/2157-7099.1000327

Copyright: (C) 2015 Sharaf HM, et al. This is an open-access article distributed under the terms of the Creative Commons Attribution License, which permits unrestricted use, distribution, and reproduction in any medium, provided the original author and source are credited. 
reared in plastic containers $(40 \times 30 \times 30 \mathrm{~cm})$ with soil base $(10$ snails/ jar) and fed on lettuce for two weeks to be acclimatized.

\section{Tested chemicals}

Two pesticides belonging to two different groups namely, Methiocarb 3,5-Dimethyl-4-(methylthio)phenyl methylcarbamate (carbamate) and Chlorpyrifos $O, O$-Diethyl O-3,5,6-trichloropyridin-2yl phosphorothioate (organophosphate), were chosen to examine their toxic effects on this serious land snail.

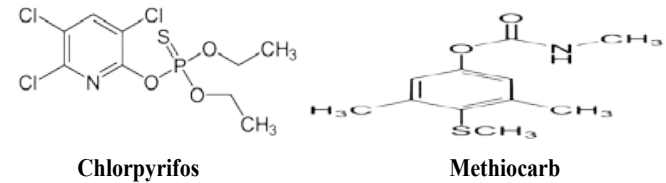

\section{Tested solution}

Serial concentrations of the two chemicals were prepared from stock solution by diluting with distilled water. These concentrations were $0.01,0.02,0.04 \mathrm{ppm}$ for Chlorpyrifos and 10,12, $14 \mathrm{ppm}$ for Methiocarb. Three replicates per each concentration were used to determine the $\mathrm{LC}_{50}$. Ten snails of the same size were placed in each glass container. An equal number was left without treatment as a check control. Experiments were checked at $24 \mathrm{~h}$ intervals up to $96 \mathrm{~h}$. The dead snails were counted and recorded. $\mathrm{LC}_{50}$ was determined according to Finney [20] by the graphic method of the curve dose-effect, using the probit analysis. In the long term exposure, half of the $96 \mathrm{~h} \mathrm{LC}$ of the tested pesticides was used and redosed every 4 days in astatic fonewal manner. Living animals, surviving the effect of the tested pesticides were sacrificed after 7 days of exposure.

\section{Biochemical measurements}

Snails digestive glands were dissected out and homogenized in distilled water $(50 \mathrm{mg} / \mathrm{ml})$ The homogenates were centrifuged at $8000 \mathrm{rpm}$ for $15 \mathrm{~min}$ at $5^{\circ} \mathrm{C}$ in refrigerated centrifuge. The deposits were discarded and the supernatants were kept in a deep freezer till use to determine the activities of Alkaline phosphatase (ALP), Alanine amino transaminase (ALT), Aspartate amino transaminase (AST) enzymes and total lipids (TL), total proteins (TP).

The activity of AST and ALT was determined according to Farkas et al. [21]. While, Alkaline phosphatase (ALP) was determined according to Bessey et al. [22]. The Total proteins (TP) were calorimetrically determined according to Bradford et al. [23] while total lipids (TL) were assayed by the method of [24].

\section{Histological studies}

The digestive gland of $H$. vestalis snails was dissected and fixed in Bouin's fluid. Paraffin sections of $5 u$ m thickness were deparaffinized, hydrated and then stained in Ehrlich' hematoxylin for 15 minute, washed rapidly in water then counter stained with $1 \%$ eosin solution for 2 minutes. Stained sections were dehydrated in alcohol and cleared in xylene, mounted on clean microscope glass slides with Canada balsam and covered by thin cover slides.

\section{Statistical analysis}

Data were calculated as Mean $\pm \mathrm{SD}$ and analyzed using analysis of variance (ANOVA) followed by Least Significant Difference (LSD) to check significance among the means. Probability of 0.05 or less was considered significant. All statistical analysis was done according to CoHort Software [25] .

\section{Results}

\section{Determination of the $\mathrm{LC}_{50}$ and $\mathrm{LC}_{25}$}

The $\mathrm{LC}_{50}$ and $\mathrm{LC}_{25}$ values of Chlorpyrifos and Methiocarb were presented in (Table 1).

\section{Biochemical studies}

The biochemical effects of three concentrations of the two pesticides on the activity of AST,ALT,ALP enzymes were presented in Table 2 and illustrated in Figure 1. Also, total proteins (TP) and total lipids (TL) were recorded in Table 3 and illustrated in Figure 2.

Activity of Aspartate amino transaminase (AST): The obtained data showed that the two tested pesticides increased the level of (AST) except at $0.01 \mathrm{ppm}$ of Chlorpyrifos which decreases the level of AST enzyme when applied against $H$. vestalis. Data also illustrate that there was no significant increase in case of Methiocarb at $10 \mathrm{ppm}$ and $12 \mathrm{ppm}$ in the activity of AST more than control. Methiocarb at $14 \mathrm{ppm}$ caused the highest increase in the activity of (AST). On the other hand, 0.02 ppm and $0.04 \mathrm{ppm}$ Chlorpyrifos increased the level of (AST). While Chlorpyrifos at $0.01 \mathrm{ppm}$ decreased the level of AST (Table 2 and Figure 1).

Activity of Alanine amino transaminase (ALT): The data obtained

\begin{tabular}{|c|c|c|c|}
\hline \multirow[b]{2}{*}{ Pesticides } & \multirow{2}{*}{ Exposure period } & 96 hrs & 7 days \\
\hline & & LC50 & LC25 \\
\hline Chlorpyrifos & & 0.010 & 0.005 \\
\hline Methiocarb & & 8.8 & 4.4 \\
\hline
\end{tabular}

Table 1: LC50 and LC25 Chlorpyrifos and Methiocarb Pesticides with their exposure time.

\begin{tabular}{|c|c|c|c|c|}
\hline Character & Treatment & $\begin{array}{l}\text { AST } \\
\left(\mathrm{U} \times 10^{3} / \mathrm{mg}\right)\end{array}$ & $\begin{array}{l}\text { ALT } \\
\left(\mathrm{U} \times 10^{3} / \mathrm{mg}\right)\end{array}$ & $\begin{array}{l}\text { ALP } \\
\left(\mathrm{U} \times 10^{3} / \mathrm{mg}\right)\end{array}$ \\
\hline Control & & $202.69 \pm 13.18$ & $144.89 \pm 5.88$ & $55.16 \pm 1.69$ \\
\hline \multirow{3}{*}{ Methiocarb } & 10 pmm & $216.39 \pm 27.56$ & $168.70 \pm 12.00$ & $61.06 \pm 2.96$ \\
\hline & 12 ppm & $270.36 \pm 1.43$ & $242.08 \pm 4.81$ & $94.63^{* *} \pm 1.74$ \\
\hline & 14 ppm & $424.04^{* *} \pm 50.13$ & $283.11 \pm 8.95$ & $108.42^{* \star} \pm 12.83$ \\
\hline \multirow{3}{*}{ Chlorpyrifos } & $0.01 \mathrm{ppm}$ & $159.19 \pm 9.33$ & $139.14 \pm 4.17$ & $74.29 \pm 0.31$ \\
\hline & $0.02 \mathrm{ppm}$ & $236.38^{\star} \pm 104.04$ & $189.73^{\star} \pm 2.49$ & $81.23^{\star \star} \pm 5.76$ \\
\hline & $0.04 \mathrm{ppm}$ & $275.00^{* *} \pm 28.07$ & $241.39^{* *} \pm 19.39$ & $118.94^{* *} \pm 3.00$ \\
\hline
\end{tabular}

Different superscripts differ from each other significantly at $\mathrm{P}<0.05$. Aspartate aminotransferase AST, Alanine aminotransferase ALT, Alkaline phosphatase ALP.

Table 2: Biochemical components (means \pm SD) of the digestive gland of the land snail, $H$. vestalis, exposed tosublethal concentrations of Methiocarb and Chlorpyrifos.

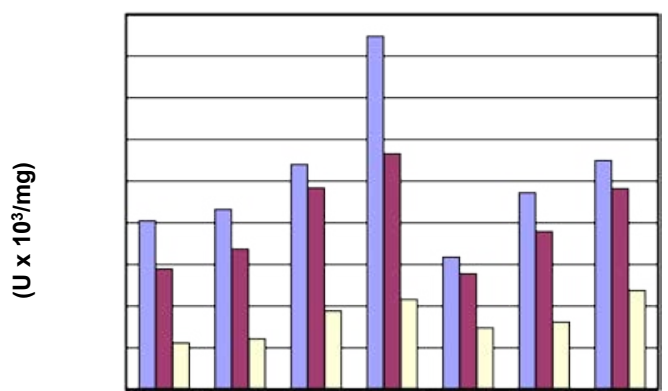

$\square$ AST $\square$ ALP

Figure 1: AST, ALT and ALP values in the digestive gland of $H$. vestalis exposed to sublethal concentrations of Methiocarb and Chlorpyrifos. 
Citation: Sharaf HM, Salama MA, Abd El-Att MS (2015) Biochemical and Histological Alterations in the Digestive Gland of the Land Snail Helicella vestalis (Locard, 1882) Exposed to Methiocarb and Chlorpyrifos in the Laboratory. J Cytol Histol 6: 327. doi:10.4172/2157-7099.1000327

\begin{tabular}{|l|l|l|l|}
\hline Character & Treatment & TL(U $\left.\times 1 \mathbf{1 0}^{\mathbf{3}} \mathbf{m g}\right)$ & $\mathrm{TP}(\mathbf{U} \times \mathbf{1 0} \mathbf{3} \mathbf{m g})$ \\
\hline Control & & $19.0 \pm 0.33$ & $1.03 \pm 0.08$ \\
\hline \multirow{2}{*}{ Methiocarb } & $10 \mathrm{ppm}$ & $19.08^{*} \pm 0.63$ & $0.88 \pm 0.08$ \\
\hline & $12 \mathrm{ppm}$ & $19.46^{*} \pm 0.31$ & $1.08^{*} \pm 0.02$ \\
\hline & $14 \mathrm{ppm}$ & $20.64^{*} \pm 0.14$ & $1.29^{*} \pm 0.34$ \\
\hline
\end{tabular}

Table 3: Biochemical components (means \pm S.D) of the digestive gland of the land snail, $H$. vestalis, exposed to sublethal concentrations of Methiocarb and Chlorpyrifos.

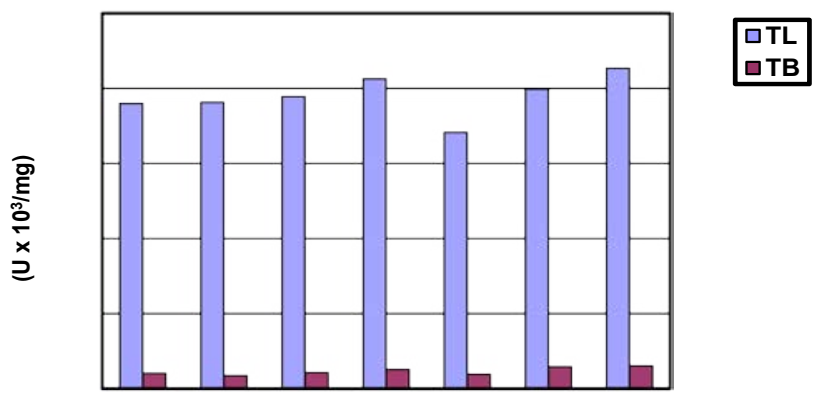

Figure 2: Total proteins and Total lipids values in the digestive gland of $H$. vestalis exposed to sublethal concentrations of Methiocarb and Chlorpyrifos.

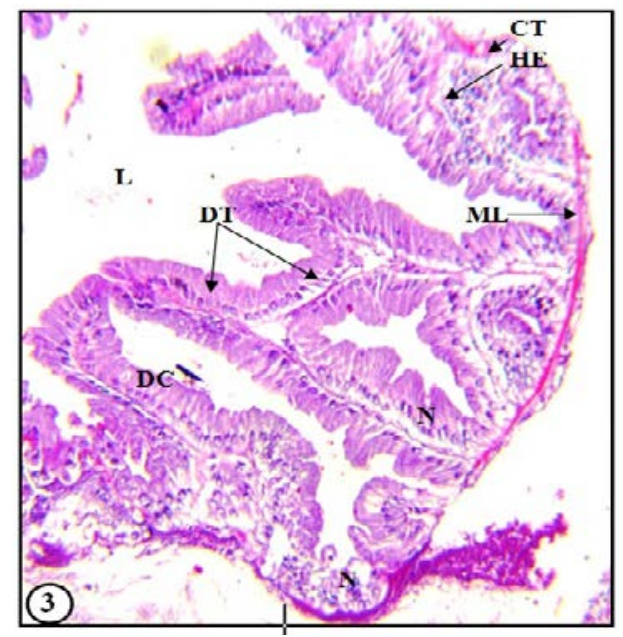

Figure 3: Photomicrograph for T.S of untreated digestive gland of Helicella vestalis showing: DC: Digestive Cell; EC: Excretory Cell; CC: Calcium Cell; HE: Hemocytes; L: Lumen; ML: Muscle Layer; N: Nucleus. H\&E 20X.

showed that the two tested pesticides increase the level of (ALT) except at $0.01 \mathrm{ppm}$ of Chlorpyrifos which decreased level of ALT enzyme when applied against $H$. vestalis. Data also illustrated that there were no significant increase in case of Methiocarb at $10 \mathrm{ppm}$ and $12 \mathrm{ppm}$ in the activity of ALT respectively. Methiocarb at $14 \mathrm{ppm}$ caused the highest increase in the activity of (ALT). On the other hand, $0.02 \mathrm{ppm}$ and $0.04 \mathrm{ppm}$ Chlorpyrifos increased the level of (ALT) while, $0.01 \mathrm{ppm}$ Chlorpyrifos decreased the level of ALT (Table 2 and Figure 1).

Activity of alkaline phosphatase (ALP): ALP activity was increased in the land snail after treatment with all tested pesticides concentrations. There were significant differences between all treatments and control. Methiocarb at $12 \mathrm{ppm}$ and $14 \mathrm{ppm}$ caused the highest increase in ALP activity respectively. Methiocarb at $10 \mathrm{ppm}$ caused the lowest increase in the level of this enzyme in comparison with control. ALP activity increased significantly in the land snail after exposure to all molluscicides concentrations. Chlorpyrifos at $0.04 \mathrm{ppm}$ and 0.02 caused the highest increase in ALP activity. Chlorpyrifos $0.01 \mathrm{ppm}$ showed the lowest increase in the level of this enzyme compared to the control (Table 2 and Figure 1).

Total lipids: The tested pesticides concentrations increased the level of total lipids in land snails and there were insignificant differences between all treatments and control except at $14 \mathrm{ppm}$ Methiocarb that caused highest increase in total lipids followed by $12 \mathrm{ppm}$ and $10 \mathrm{ppm}$. Chlorpyrifos at $0.02 \mathrm{ppm}$ and $0.04 \mathrm{ppm}$ increased the level of total lipids when applied against the snail. Chlorpyrifos at $0.01 \mathrm{ppm}$ decreased the level of total lipids fewer than control (Table 3 and Figure 2).

Total proteins: Methiocarb at $12 \mathrm{ppm}$ and $14 \mathrm{ppm}$ increased the level of total proteins when applied against the snail. Methiocarb at $10 \mathrm{ppm}$ decreases the level of total proteins fewer than control. Chlorpyrifos at $0.02 \mathrm{ppm}$ and $0.04 \mathrm{ppm}$ caused an increase in the level of total proteins. On the other hand, Chlorpyrifos at $0.01 \mathrm{ppm}$ decreased the level of total proteins fewer than control (Table 3 and Figure 2).

\section{Histopathological studies}

Histology of untreated digestive gland: The digestive gland of normally feeding untreated $H$. vestalis consists mainly of digestive tubules (DT) separated by intertubular connective tissue (CT) containing hemolymphatic sinuses and hemocytes (HE). Each tubule is surrounded by circular muscle layer (ML). Three different cell types are observed in the epithelium lining the digestive gland tubules (Figure 3), the cells are differentiated into, digestive cells (DC), calcium cells (CC) and excretory cells (EC).

Digestive cells: Digestive cells constitute the most abundant cellular component of the digestive gland tubular epithelium. Digestive cells are simple columnar epithelium. The basally located nuclei $(\mathrm{N})$ of digestive cells are rounded or oval.

Calcium cells: Calcium cells are fewer than digestive cells, occur either singly or in groups in the corners of the tubules. They have pyramidal shape with pointed distal end. Calcium cells possess apical excretory granules (EC) and large rounded nuclei (Figures 4 and 5).

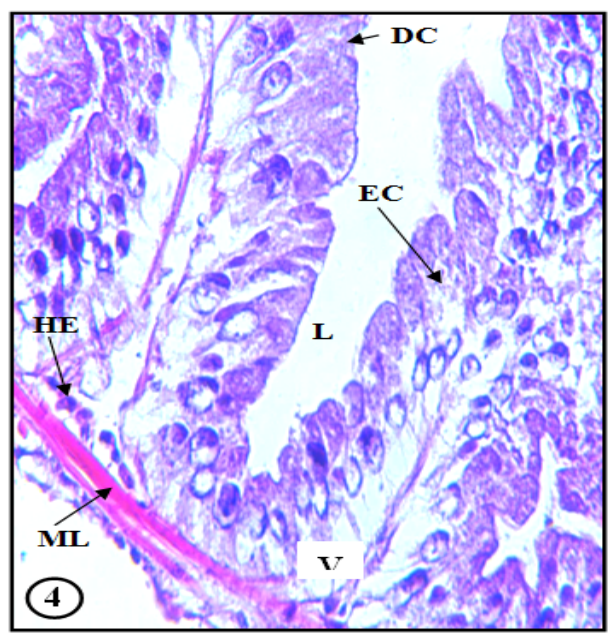

Figure 4: Higher magnification for T.S. of the digestive gland showing: DC Digestive Cell; EC: Excretory Cell; CC: Calcium Cell; HE: Hemocytes; L: Lumen; ML: Muscle Layer; V: Vacuoles; N: Nucleus. H\&E 40X. 


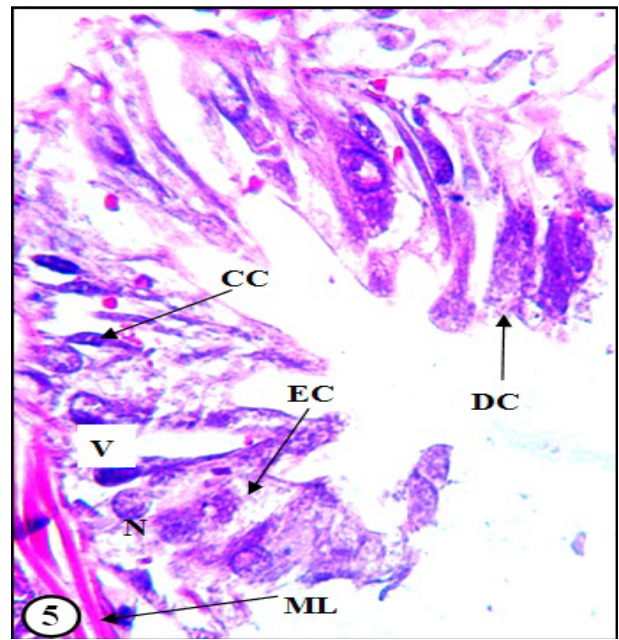

Figure 5: Higher magnification for T.S. of the digestive gland showing: DC: Digestive Cell; EC: Excretory Cell; CC: Calcium Cell; HE: Hemocytes; L: Lumen; ML: Muscle Layer; V: Vacuoles; N: Nucleus. H\&E 60X.

Excretory cells: Excretory cells have a rounded shape. They are characterized by the presence of a single large vacuole (V) (Figures 4 and 5).

After treatment with LC25 of methiocarb: few tubules with severe atrophy were mingled in some places. Hemocytic infiltration (HI) was frequently observed and the basement membrane of tubules appeared ruptured. The digestive cells show accumulation of large numbers of dark granules (DG) and appear to undergo extensive breakdown into membrane bound vesicles. Calcium cells were packed with enlarged calcium spherules and exhibited pyknotic nuclei (PN). The cytoplasm of most calcium cells was replaced by large vacuoles containing darkly stained granules. Excretory cells showed increased number of excretory granules with cellular debris and necrotic areas (NA) (Figures 6-8).

After treatment with LC25 of chlorpyrifos: destruction of most tubule was evident, the basement membrane and the tubular connective tissue (BM) showed severe structural disruption. Digestive cell cytoplasm appeared to be nearly devoid of cytoplasmic granules and there was a marked reduction in number of calcium cells and the size of calcium spherules. In addition, calcium cells contained an increased deposition of calcified dark granules (DG) with vacuolated cytoplasm (V) and karyolitic nuclei. Most excretory vacuoles of excretory cells appear with highly decomposed cellular elements (Figures 9-11).

\section{Discussion}

The present study revealed that both Methiocab and Chlorpyrifos caused an increase in the activities of AST, ALP and ALT in the land snail, $H$. vestalis. The transaminases enzymes; AST, ALP and ALT were not solely located in hepatocytes but rather are found in many body organs. Also, the increase in their activities could be due to a variety of conditions including muscle damage, intestinal and hepatic injury and toxic hepatitis [21]. On the other hand, the decrease in activities of AST and ALT might be due to either leakage of enzymes into extracellular compartments or due to actual enzymes inhibition by these molluscicides. Thus, the deviation of both enzymes activities out of the normal range could lead to biochemical impairment, lesions of the tissues and cellular functions [26]. Accordingly, the elevations or reductions in the activities of AST and ALT enzymes in tissues of both E. vermiculata and M. cantiana treated with molluscicides might be partially due to cell injury of their different organs and this might lead to disturbances in their enzymatic systems $[8,27,28]$. These results are supported by the findings of Radwan et al.[26] who has found that carbamate compounds led to significant elevation of the activity of AST and ALT when applied against the land snail, Theba pisana.

The present data indicated that the two tested compounds increased the level of ALP in $H$. vestalis. These compounds presented an increase of total lipids (TL) and total proteins (TP) in the digestive gland. The current results are coincide with the findings of Abd-El-All [9] who observed that Niclosamide increased the level of total lipids and total proteins more than control after 24, 48, 72 and 96h of exposure when applied against the land snail, E. vermiculata. Meanwhile, Chlorpyrifos at $0.01 \mathrm{ppm}$ decreased the level of total proteins and total lipids less than control. Methiocarb $10 \mathrm{ppm}$ decreases the level of total proteins.

The decrease in the level of both TP and TL might be partly resulted from imbalance between the rate of synthesis and the rate of

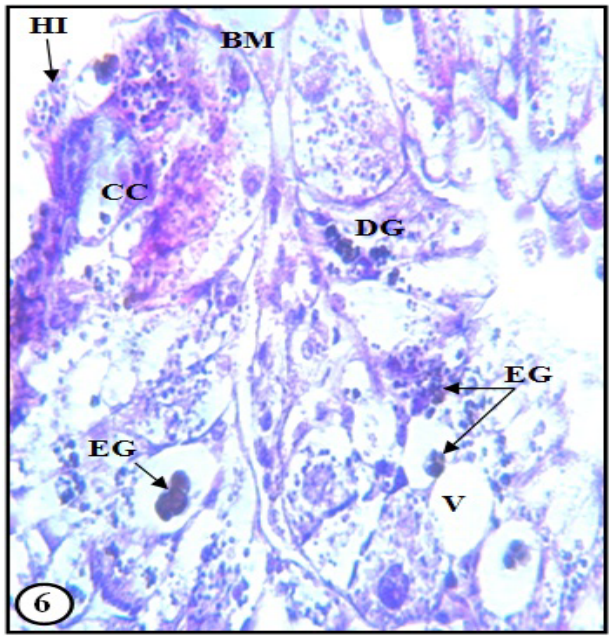

Figure 6: Photomicrograph for T.S. of sections of digestive gland treated with Lc25 Methiocarb showing: BM: Ruptured Basement Membrane; CC: Calcium Cell; DG: Dark Granules; EG: Excretory Granules; HI: Hemocyte Infiltration. H\&E 20X.

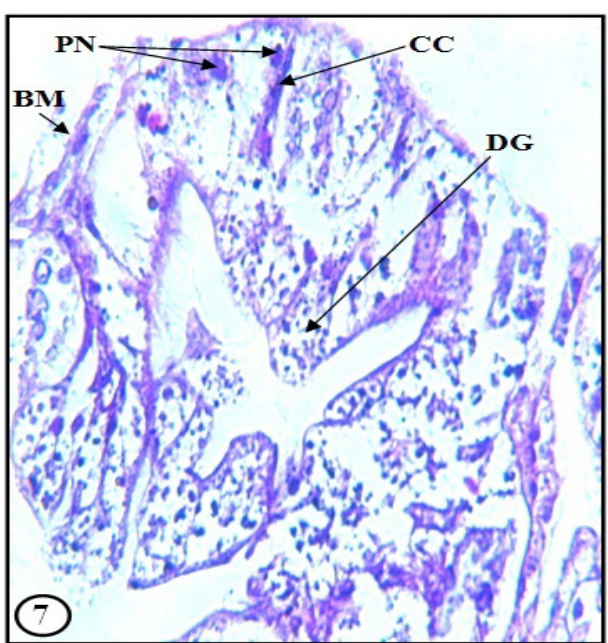

Figure 7: Higher magnification for T.S. of the digestive gland treated with LC25 Methiocarb showing: BM: Ruptured Basement Membrane; PN: Pyknoticnuclei; CC: Calcium Cell; DG: Dark Granules. H\&E 40X. 


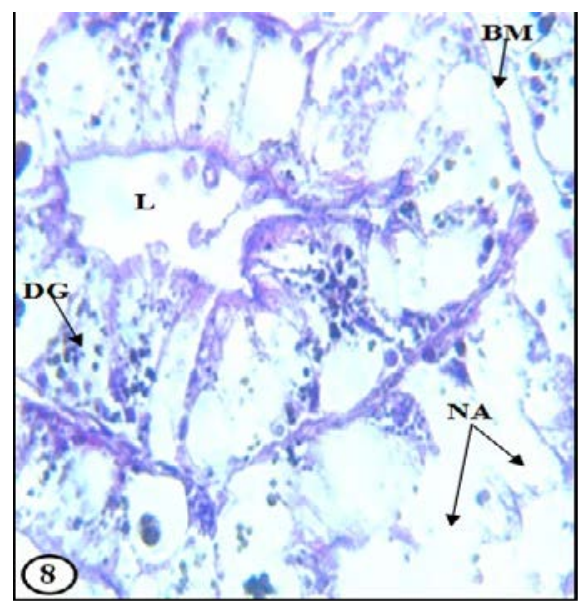

Figure 8: Higher magnification for T.S. of the digestive gland treated with Lc25 Methiocarb showing: Ruptured Basement Membrane BM; NA: Necrotic Areas; PN: Pyknotic Nuclei; CC: Calcium Cell; DG: Dark Granules; HI: Hemocyte Infiltration. H\&E 40X.

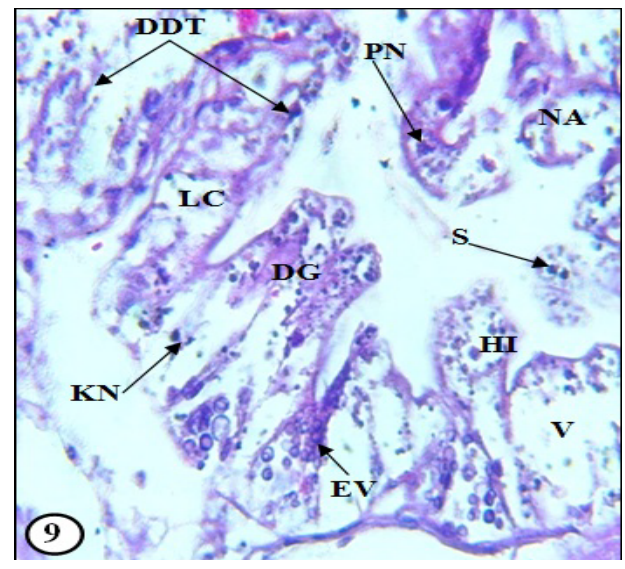

Figure 9: Photomicrograph for T.S. of sections of digestive gland treated with Lc25 Chlorpyrifos: DDT: Destructed Digestive Tubules; DG: Dark Granules; EV: Excretory Vesicles; HI: Hemocyte Infiltration; KN: Karyolytic Nuclei; LC: Lytic Cells; NA: NecroticAreas; PN: Pyknotic Nuclei; S: Secretions; V: Vaculation.. H\&E 20X.

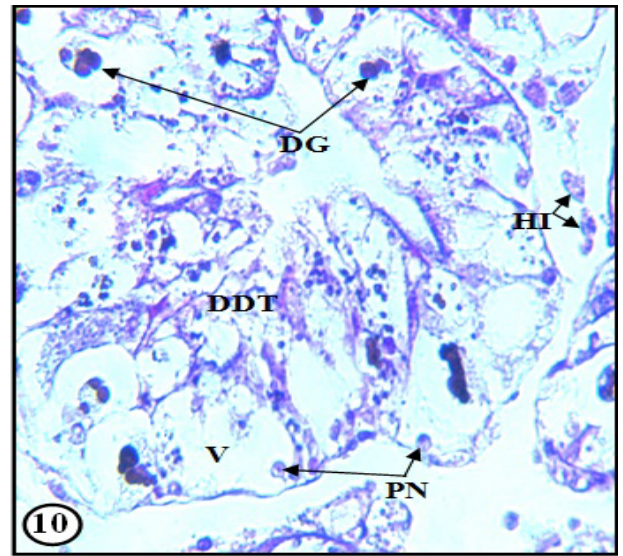

Figure 10: Higher magnification for T.S. of the digestive gland treated with Lc25 Chlorpyrifos showing: DDT: Destructed Digestive Tubules; HI: Hemocyte Infiltration; KN: Karyolytic Nuclei; LC: Lytic Cells; NA: Necrotic Areas; PN: Pyknotic Nuclei; S: Secretions; V: Vaculation. H\&E 40X.

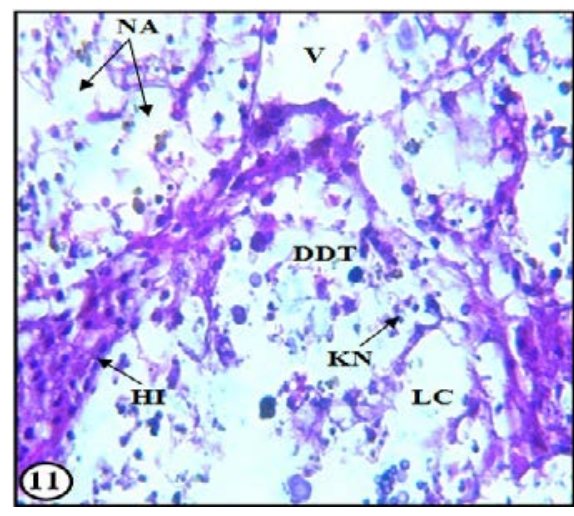

Figure 11: Higher magnification for T.S. of the digestive gland treated with Lc25 Chlorpyrifos showing: DDT: Destructed Digestive Tubules; HI: Hemocyte Infiltration; KN: Karyolytic Nuclei; LC: Lytic Cells; NA: Necrotic Areas; PN: Pyknotic Nuclei; S: Secretions; V: Vaculation. H\&E 40X.

degradation. Abd-El-All [9] reported that the depression in total lipids might be due to decline in lipid synthesizing capacity or to an increase in the hydrolysis of hepatic lipids to combat the stress conditions. The harmful effect of chemical compounds could be attributed to enhancement of energy utilization or destruction of cells organelles of treated snails that may lead to inhibition of protein synthesis [29].

Also, the present results proved that these chemicals caused alterations in some biochemical elements which could lead to serious metabolic and cellular damage. In general, the two molluscicides adversely affected the activities of three vital enzymes, total lipids and total proteins when applied against the tested land snail. However further, studies are needed to clearly elucidate the most effective mode of action of these chemical compounds on such land snails.

The present study revealed also many histological changes in the digestive gland of H.vestalis after exposure to sublethal concentrations (LC25) of both Methiocarb and Chlorpyrifos. These alterations included severe tubular disruption, vaculation; pyknotic nuclei and necrosis of digestive tubules .These findings are in agreement with [18] who found that Methomyl was more toxic than Methiocarb on some land snails. They also reported that their digestive gland tissues suffered from hemocytes infiltration, bizarre nuclei ranged from karyolysis to severe karyorrhexis and complete pyknosis. These results are in agreement also with [19] who studied the effect of Thiometoxam on the histology and total carbohydrates, proteins and lipids of the hepatopancreas of Helix aspersa. They found a significant decrease in total proteins, lipids, and carbohydrates as well as degeneration of the digestive tubules and breakdown of the basement membrane.

The present histopathological and biochemical results revealed that Chlorpyrifos has much more toxic effects than Methiocarb on the land snail $H$. vestalis.

\section{Authors' Contributions}

Hesham M.Sharaf, Mohamed A. Salama and Mahmoud S. Abd ElAtti are the main investigators, performed all experimental work and paper writing, carried out data analysis the authors read and approved the final manuscript.

\section{Acknowledgement}

The authors wish to thank Dr. Abdallah Ibrahium Prof. of Environmental studies, Faculty of Science, Ain Shams, Cairo, Egypt, for critically reviewing the paper and before that he was encouraging us for doing our best to achieve this study. 
Citation: Sharaf HM, Salama MA, Abd El-Att MS (2015) Biochemical and Histological Alterations in the Digestive Gland of the Land Snail Helicella vestalis (Locard, 1882) Exposed to Methiocarb and Chlorpyrifos in the Laboratory. J Cytol Histol 6: 327. doi:10.4172/2157-7099.1000327

Page 6 of 6

\section{References}

1. El-Okda, MMK (1981) Land mollusca infestation and chemical control in ElIsmailia Governorate. Agricultural Research Review 62: 279-287.

2. El-Okda MMK, Emara MM, Selim AM (1989) The response of the harmful and useful terrestrial mollusca towards several toxicants. Efficacy of six toxicants under laboratory conditions. Alexandria Science Exchange 10: 375-385.

3. Lokma, MHE (2007) Studies on some terrestrial gastropods injurious to field crops at Sharkia governorate. M. Sc. Thesis, Faculty of Agriculture, Zagazig University, Egypt.

4. Shahawy WA, Hendawy AS, Abada AE, Kassem AA (2008) Land snails infesting rice plants and their accompanied parasites and predators at $\mathrm{Kafr}$ El-Sheikh governorate. Egyptian Journal of Agricultural Research 86: 971-980.

5. Ramzy RR (2009) Biological and ecological studies on land snails at Assiut, Egypt M. Sc. Thesis, Faculty of Science, Assiut University, Egypt.

6. Gabr, WM, Fatma KK, SS Hussien SS (2007) Molluscicidal activity of some pesticides against glassy clover Monacha obstructa. Egypt J Agric Res 8566 2017-2025.

7. Heikal MH (2015) Biological aspects and population dynamics of three terrestrial snails infesting fruit trees in Egypt. Int J Adv Res Biol Sci 2: 169-180.

8. Heiba FN, Al-Sharkawy IM, Al-Batal AA (2002) Effects of the insecticide Lannate, on the land snails, Eopania vermiculata and Monacha contiana, under laboratory conditions. J Biol Sci 2: 8-13.

9. Abd-El-All SM (2004) Toxicity and biochemical response of Eobania vermiculata land snail to Niclosamide molluscicide under laboratory and field conditions. J Agric Sci Mansoura Univ 29: 4751-4756.

10. Ismail AA Abd-Allah, SA El-Massry, Hegab AM (2005) Evaluation of certain chemicals and insecticides against Monacha cartusiana snails infesting some vegetable crops at Sharkia Governorate. J Agric Sci Mansoura Univ 30: 6283-6292.

11. Zedan HA, Mortada MM, ShoeiB AA (2006) Assessment of molluscicidal activity of certain pesticides against two land snails under laboratory and field circumstances at Dakahlia Governorate. J Agric Sci Mansoura Univ 31: 3957-3962.

12. Genena MAM, Mostafa FAM (2008) Efficacy of four pesticides applied agains the land snail, Monacha cantiana (Montagu) (Gastropoda: Helicidae) at three exposure periods. J Agric Sci Mansoura Univ 27: 7767-7775.

13. Kassem FA (2004) Metaldehyde inducing histological alterations of brown and white garden snails' digestive glands. J Agric Sci Mansoura Univ 29: 925-933.

14. Hegab AMI, Arafa AAI, Hilmy A El-Sayed (2013) Efficacy of Methomyl and Copper Sulphate against Eobania vermiculata (Muller) and Helicella vestalis (Preiffer) snail under laboratory and field conditions. Annals of Agric Sci Moshtohor 51: 271-275.
15. Genena MAM (2003) Studies on the terrestrial gastropods at Dakahlia Governorate, M.Sc. Thesis, Faculty of Agriclture, Massoura University, Egypt.

16. Racke KD (1992) The environmental fate of Chlorpyrifos. Rev Environ Contam Toxicol 131: 1-52.

17. Christensen K, Harper B, Luukinen B, Buhl K, Stone D (2009) Chlorpyrifos Technical Fact Sheet. National Pesticide Information Center.

18. Hamed SS, Abdelmeguied EN, Essawy EA, Radwan AH, Hegazy EA (2007) Histological and ultrastructural changes induced by two carbamate molluscicides on the digestive gland of Eubania vermiculata. Journal of Biological Science 7: 1017-1037.

19. Hamlet AS, Bensultan S, Djekoun M, Yassi F, Berrebbah H (2012) Histological changes and biochemical parameters in the hepatopancreas of terrestrial gastropod Helix aspersa as biomarkers of neonicotinoid insecticide exposure. African Journal of Biochemistry 11: 16277-16283.

20. Finney DJ (1971) Probit analysis (3rdedn.) Combrige University Press, London.

21. Farkas JP, Farkas P, Hyde D (2004) Liver and Gastroenterology Tests. In: Lee $M$ (ed.) Basic Skills in Interpreting Laboratory Data (3rdedn.) American Society of Health System Pharmacists Inc., USA.

22. Bessey OA, Lowry OH, Brock MJ (1946) A Method For The Rapid Determination Of Alkaline Phosphates With Five Cubic Millimeters Of Serum. J Biol Chem 164: 321-329.

23. Bradford MM (1976) A rapid and sensitive method for the quantitation of microgram quantities of protein utilizing the principle of protein-dye binding. Anal Biochem 72: 248-254

24. Knight JA, Anderson S, Rawle JM (1972) Chemical basis of the sulfo-phosphovanillin reaction for estimating total serum lipids. Clin Chem 18: 199-202.

25. CoHort Software (2004) CoStat. California, USA.

26. Radwan MA, El-Wakil HB, Osman KA (1992) Toxicity and biochemical impact of certain Oxime carbamate pesticides against terrestrial snail, Theba pisana Muller). J Environ Sci Health Part B: Pestic Food Contam Agric Wastes 27 759-773.

27. Mahmoud MB (2006) Biological and histological impact of the insecticides reagent and mimic on Biomphalaria alexandrina snails. Egypt $\mathrm{J}$ Zool 46: 11-21.

28. Radwan MA, Mohamed MS (2013) Imidaclpride induced alterations in enzyme activities and energy reverse of the land snail, Helix aspersa. Ecotoxicology and environmental Safety 95: 91-97.

29. Eissa SH, Rizk ET, Abou-Shafey AE, Mona MH, Atlum A (2002) Toxicological effect on Euphorbia peplus water suspension on heamocytes of the fresh water snails, Biomphalaria alexandrina and Lanistes carinatus. Proc LCBS 2: 417-447. 